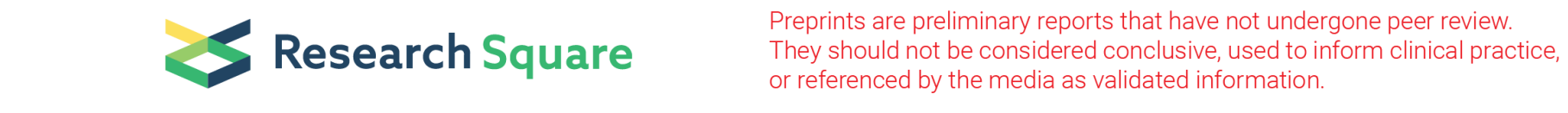

\title{
Effect on the Yield of Ginger As Intercropping With Different Crops.
}

Prabesh Devkota ( $\square$ prabeshdevkota30@gmail.com )

IK Gujral Punjab Technical University Jalandhar https://orcid.org/0000-0002-7262-8564

Research Article

Keywords: Intercropping, Companion Crop, Ginger, Different Crops, Mono Crop, Zingiber officinale Rosc., Zea mays L., Rhizome, Nepal, Sindhuli.

Posted Date: February 11th, 2022

DOI: https://doi.org/10.21203/rs.3.rs-1343672/v1

License: (c) (1) This work is licensed under a Creative Commons Attribution 4.0 International License. Read Full License 


\section{Abstract}

Ginger ( Zingiber officinale) is one of the major high-value cash crops in Nepal. Low yield, conventional farming, and limited access to production resources such as improved cultivars, production technologies, and extension services are the existing problems of Nepali ginger farmers. In this study, we conducted intercropping of ginger with different crops. This research aimed to explore the appropriate ginger farming technology considering yield, income, and environment. The crops selected for intercropping were Maize [ Zea mays L.] (Cereal Crop), Chilli [ Capsicum annuum L.] (Spices or Cash Crop), Okra [ Abelmoschus esculentus L.] (Vegetable Crop) and Pigeon Pea [ Cajanus cajan L.] (Leguminous or Pulses) and as cultivated as duration of one season crops (i.e. 9 months). The experiment was conducted in a randomized complete block design with 4 replications. The difference among the treatments on the yield of ginger was found to be non-significant. However, among all the treatments, yield from ginger and maize combination was highest at $22.7 \mathrm{~kg}$ followed by control i.e. ginger as a mono crop. The lowest yield was obtained from ginger with pigeon pea. The number of tillers/ clump and plant height was found to be significant. The highest number of tillers/ clump at 16.0 was in ginger and maize combination and lowest at 10.3 in ginger and pigeon pea combination. The height of the plant was highest at $70.0 \mathrm{~cm}$ in ginger and pigeon pea combination. The total return of ginger and companion crop was calculated at a recent market price. The total return was highest in ginger and okra combination at Rs. 3587 followed by ginger and maize combination at Rs. 3291.5. The lowest return was obtained from ginger (control) at Rs. 756.

\section{Introduction}

Ginger (Zingiber Officinale Rosc.) is in the family Zingiberaceae, which also includes turmeric (Curcuma longa), cardamom (Elettaria cardamomum) and galangal. It is a perennial herbaceous monocotyledon, usually grown as annual, is known to human generations as a medicinal and spice crop. Ginger originated in Maritime Southeast Asia and was likely domesticated first by the Austronesian peoples. It is a plant of very ancient cultivation and the spice has long been used in Asia. It is a traditional cash as well as spices crop among the hill and Mid-hill farmers of Nepal. It is one of the major high-value cash crops and high-value exportable commodities grown in the mid-hills of Nepal. It is grown as mono crops in some parts of Nepal such as Jhapa, llam, Bhojpur, Salyan etc. The crop is also being grown as an intercrop with other crops. The economic part is the underground rhizome, which is pungent and aromatic and used for culinary purposes, in ginger bread, biscuits, cakes, puddings, soups and pickles. Ginger is traded in three basic forms green (fresh), pickled or preserved and dry. Only dry ginger (whole, peeled or sliced) is regarded as a spice; green or fresh ginger is considered basically as vegetable, while pickled or preserved ginger is destined largely for the trade connected with Chinese and Japanese cuisine. In addition, ginger oil and oleoresins are also traded. Although a number of countries produce ginger, exports of dry ginger on a significant scale are limited to India and China, the two dominant suppliers, followed by Nigeria, Sierra Leone, Australia, Fiji, Bangladesh, Jamaica, Nepal and Indonesia. It has been noticed that when the supply of nutrients and water is adequate, the yield reduction of ginger from intercropping is low and can be recovered easily from the companion crop at the same time.

Ginger requires a tropical or sub-tropical climate. It thrives well up to an altitude of $1500 \mathrm{~m}$ above MSL in the Himalayas, the optimum being $300-$ $900 \mathrm{~m}$ (CSIR 1976). The base temperature requirement is $13^{\circ} \mathrm{C}$ and upper limit $32^{\circ} \mathrm{C} / 27^{\circ} \mathrm{C}$ (day/night) (Hackett \& Carolane 1982 ), the favourable range being $19-28^{\circ} \mathrm{C}$. The optimum soil temperature for germination is between $25-26^{\circ} \mathrm{C}$ and for growth $27.5^{\circ} \mathrm{C}$ (Evenson, Bryant \& Asher 1978 ).

Ginger has wider adaptability for different soil types, and for higher yield the soil should be loose, friable and offer minimum resistance to rhizome development. Well drained soil with at least $30 \mathrm{~cm}$ depth is essential, but by adopting bedding and surface mulching, shallower soil can be utilized satisfactorily (Whiley 1974). As depth of soil increases, it's suitability for cultivation also increases (Cho et al. 1987). Compact clay soils which are subject to water logging or coarse sands without water holding capacity, gravelly soils or those with hard pan are not conducive for the production of high yielding healthy plants (Lawrence 1984).

Planting depth may vary depending upon seed size, soil type and soil moisture content. In general, bolder seeds are planted deeper and smaller seeds at a shallow depth. Seed rhizome pieces are generally planted at 4-10 cm depth (Kannan \& Nair 1965; Aiyadurai 1966; Vevai 1971; Paulose 1973; Lee, Asher \& Whiley 1981; Mohanty, Naik \& Panda 1990; Wilson \& Ovid 1993). As depth of planting influences the time of germination, it is necessary to plant at optimum depth.

\section{Materials And Methods}

The crops selected for intercropping were Maize [Zea mays L.] (Cereal Crop), Chilli [Capsicum annuum L.] (Spices or Cash Crop), Okra [Abelmoschus esculentus L.] (Vegetable Crop) and Pigeon Pea [Cajanus cajan L.] (Leguminous or Pulses) and as cultivated as duration of one season crops (i.e. 9 months).

The experiment was conducted from 22nd March, 2021 to 9th Jan 2022. The treatments were arranged in a Randomized Complete Block Design (RCBD) with 4 replications. The plot was $5 \mathrm{~m}$ long and $2 \mathrm{~m}$ wide and each plot consisting 16 rows of $30 \mathrm{~cm}$ wide. Out of 16 rows, 12 rows of ginger and 4 rows of companion crops. The space between the rhizomes was $25 \mathrm{~cm}$, maize and okra as $25 \mathrm{~cm}$ spacing and chilli and pigeon pea as $30 \mathrm{~cm}$. The variety of ginger was local, maize as Arun, chilli as Suryamukhi, okra as Pusa Sawami, and pigeon pea as Local. Maize, Pigeon Pea and Okra were sown and Chilli transplanted on 18th April 2021. As stated earlier, ginger was sown on 22nd March, 2021. Fertilizer was applied as basal dose and top dressing. The rate applications was 75:50:50 kg NPK/ha. Total phosphorous and half potash was applied as basal, half nitrogen 60 DAS and half nitrogen with half dose of 
potash 90 DAS. The source of fertilizer was Urea, TSP and Muriate of Potash. Seed treatment was done prior to sowing dipping in Dithane M-45 solution $(0.3 \%)$ for 30 minutes. Dithane M-45 was sprayed 4 times 15 days interval. The crops were harvested on:

Ginger- 9th Jan 2022

Maize- 23rd July 2021

Okra- 12th June, 2021 to 19th August, 2021 (Total 17 harvestings)

Chilli- 1st July, 2021 to 19th August, 2021 (Total 7 harvestings)

Pigeon Pea - 30th Dec. 2021

\section{Results And Discussion}

The crop yield depends on many contributing factors such as weather, plant genotype, and management practice. In this experiment, we used highyielding selected local cultivar, bio-pesticides, and chemical fertilizers and pesticides based on the actual need, dose, and soil fertility status. The quality of seed rhizome was poor which resulted into poor germination. F-test was used to statistically analyze the yield and yield components (Table 1).

The difference among the treatments on the yield of ginger was found to be non-significant. However, among all the treatments, yield from ginger and maize combination was highest at $22.7 \mathrm{~kg}$ followed by control i.e. ginger as a mono crop. The lowest yield was obtained from ginger with pigeon pea. The number of tillers/ clump and plant height was found to be significant. The highest number of tillers/ clump at 16.0 was in ginger and maize combination and lowest at 10.3 in ginger and pigeon pea combination. The height of the plant was highest at $70.0 \mathrm{~cm}$ in ginger and pigeon pea combination. The total return of ginger and companion crop was calculated at a recent market price. The total return was highest in ginger and okra combination at Rs. 3587 followed by ginger and maize combination at Rs. 3291.5. The lowest return was obtained from ginger (control) at Rs. 756 .

Table 1. Yield and yield components of ginger as intercropping

\begin{tabular}{|lllllll|}
\hline S.No. & Crops & Plant height $\mathbf{( c m )}$ & Average no. of tillers/clump & Yield $(\mathbf{k g})$ & Total Return (Rs.) & Texture of Rhizome \\
\hline 1. & Ginger and Maize & 59.8 & 16.0 & 22.7 & 3291.5 & Fiberless \\
\hline 2. & Ginger and Okra & 56.3 & 15.1 & 21.1 & 3587 & Fiberless \\
\hline 3. & Ginger and Chilli & 50.7 & 12.9 & 18.6 & 1860 & Fiberless \\
\hline 4. & Ginger and Pigeon Pea & 70.0 & 10.3 & 12.8 & 2496 & Fiberless \\
\hline 5. & Ginger (Control) & 55.2 & 15.9 & 21.6 & 756 & Fiberless \\
\hline F-test & & S & S & 23.2 & & \\
\hline CV (\%) & 13.5 & 15.6 & & \\
\hline
\end{tabular}

\section{Conclusion}

The ginger grown as intercropping seems to be profitable. Ginger can be grown as intercropping with other cash crops or maize. This also proved that maize and ginger intercrop combination will enable farmers to obtain the benefits of the two crops in the intercrop without losing out.

\section{References}

- Wikipedia, https://en.wikipedia.org/wiki/Ginger

- Kalimati Fruits and Vegetable Market Development Board, https:// https://kalimatimarket.gov.np/price

- Kandiannan, K., K. Sivaraman, C.K. Thankamani and K.V. Peter 1996 Agronomy of Ginger- a review. J of Spices and Aromatic Crops 5(1): 127. https://www.researchgate.net/publication/259043899_Kandiannan_K_K_Sivaraman_CK_Thankamani_and_KV_Peter_1996_Agronomy_of_Ginger_a_review_J_of_Spices_and_Aromatic_Crops_51_1-27

- Rudra Baral, Bishnu Prasad Kafle, Dinesh Panday, Jiban Shrestha and Doohong Min, 2021. Adoption of Good Agricultural Practice to Increase Yield and Profit of Ginger Farming in Nepal. DOI: https://doi.org/10.2478/johr-2021-0009 


\section{Declarations}

Competing interests: The authors declare no competing interests. 